\title{
WAHDAH ISLAMIYYAH PALU: ON CONTEMPORARY ISLAMIC LEGAL ISSUES IN THE INTERNET
}

\author{
Rusli \\ Institut Agama Islam Negeri (IAIN) Palu \\ Jl. Diponegoro No. 23 Kota Palu Suawesi Tengah \\ Email: rusli_mochtar@yahoo.com
}

\begin{abstract}
This paper deals with one of the Islamic organizations in Palu, Wahdah Islamiyah (Islamic Unity), in terms of theological and contemporary Islamic legal issues. The source of analysis is the website that Wahdah Islamiyah runs online. The paper concludes that Wahdah Islamiyah is influenced by the relatively strict theology of Wahhābism in religiosity and morality. Therefore, in legal issues, Wahdah Islamiyah embraced and accommodated relatively conservative views with various issues in relation to theological issues and Islamic legal issues such as women's, social, economic, and political issues. From these views, it can be argued that their aim is to preserve the identity by constructing the concepts of shirk and bid'ah and reinforcing the relatively rigid juristic tradition to become the citadel from the attacks of doctrine seeking to demolish the building of Salafism.
\end{abstract}

Abstrak. Artikel ini membahas salah satu organisasi Islam di Palu, Wahdah Islamiyah, dalam kaitannya dengan isu-isu hukum Islam kontemporer. Sumber analisis adalah website yang dijalankan oleh Wahdah Islamiyah secara online. Tulisan ini menyimpulkan bahwa: Wahdah Islamiyah dipengaruhi oelh teologi Wahabi dalam religiusitas dan moralitas. Oleh karena itu, Wahdah Islamiyah mereka menganut dan mengakomodasi pandangan-pandangan yang relatif konservatif dengan berbagai isu dalam kaitannya dengan isu akidah dan teologi, fikih perempuan, sosial, ekonomi, dan politik. Dari pandangan-pandangan tersebut dapat dikatakan bahwa tujuannya adalah menjaga identitas dengan mengkonstruksi konsep-konsep bid'ah dan syirik dan memperkuat tradisi fikih yang relatif rigid untuk menjadi benteng dan tameng dari serangan-serangan ajaran yang berusaha untuk memperkeruh bangunan Salafi.

Kata kunci: Wahdah Islamiyah, Wahhabi theology, Islamic legal issues

DOI: https://doi.org/10.24239/jsi.v14i2.489.233-251 


\section{Introduction}

Wahdah Islamiyah is considered by most people as a Salafi movement influenced by theology of Wahhabi and jurisprudence proposed by Saudi clerics, especially those incorporated in the Saudi Fatwā Committee (al-Lajnah al-Dā'imah li al-Buhūth al'Ilmiyyah wa al-Iftā). It was established to prepare research reports ready for discussion among senior clerics and to issue various fatwās on individual issues. That is, by responding to the public who asked for fatwās in the field of Islamic faith, worship, and social.

The relationship between the two is because the founders of Wahdah Islamiyah are mostly graduates from one of the universities in the two sacred lands, Mecca and Medina. After graduation, they returned to Indonesia and brought the ideology and teachings of Salafi Wahhabi transmitted by his teachers, such as 'Abd al-'Azīz Ibn Bāz, al-'Uthaymīn, and others.

How is exactly Wahdah Islamiyah's view related to various contemporary theological and Islamic legal issues? The following article will discuss the various theological and issues of figh constructed by the members of Wahdah Islamiyah, especially those contained on its website.

\section{Brief History of Wahdah Islamiyah in Palu}

Initially, Wahdah Islamiyah was founded on June 18, 1988 in Makassar with its original name Fathul Muin Foundation. This name is derived from the name of a charismatic scholar from South Sulawesi named KH. Fathul Mu'in Daeng Mangading. In order to avoid the impression of individual cults and for the purpose of establishing a unity institution of the Ummah, on 25 February 2000, Fathul Mu'in Foundation transformed into Wahdah Islamiyah Foundation meaning "Islamic Unity". On May 25, 2000, the name Wahdah Islamiyah Foundation was changed to Wahdah Islamiyah Pesantren Foundation. 
Since the development of da'wah (Islamic preaching) was very rapid, in the second meeting of Wahdah Islamiyah Pesantren Foundation on 14 April 2002 (1 Shafar 1422) was agreed to establish a mass organization of the same name, namely Wahdah Islamiyah (hereinafter written WI). Subsequently, WI was registered and became an official organization with a Registered Certificate from the Directorate General of National Unity and Politics of the Ministry of Home Affairs in Jakarta, No. 57 / D.III.2 / VI / 2008. The main purpose of this change is to meet the need for dissemination and development of $d a^{\prime}$ wah not only in South Sulawesi, but also throughout Indonesia. It is also part of a strategy to build WI branches across Indonesia by 2015.

Historically, at a glance WI may be considered a splinter group of Muhammadiyah Islamic organizations. This can be seen from the following facts. Firstly, the founders of WI, such as Muhammad Zaitun Rasmin, Muhammad Qasim Saguni, and Haris Abdurrahman, had been members of the Muhammadiyah Student Association. Second, KH. Fathul Mu'in is a mentor for the founders of WI and also for the Muhammadiyah Student Association (IMM). Through this figure, WI has an ideological relationship close to the Darul Islam movement. The main reason the founders of WI broke away from Muhammadiyah was because of their opposition to the New Order instructions that all organizations should use the sole principle of Pancasila as the foundation of the organization.

If it is seen from the context of its emergence, WI grew up in a state of nations undergoing adaptation of the transnational "imported" ideology of the Middle East and the process of state accommodation on the aspirations of Muslims. This movement derives an ideological "ammunition" from the publications of Muslim Brotherhood leaders. Secondly, through direct contact with the two holy cities-Mecca and Medina, namely through the delivery of young cadres to study in Saudi Arabia. 
In its development, Wahdah Islamiyah, which is an Islamic movement that emerged from Indonesian traditions and culture and was much influenced by the ideology of the revivalist Middle East by developing a movement oriented to Islamic purification based on the culture of Indonesian society, spread to other regions of the archipelago. In 2009, Wahdah Islamiyah has 35 branches and 43 affiliates in 11 provinces in Indonesia. On December 30, 2012, Wahdah Islmiyah can develop and establish branches of organizations throughout the Provincial Capitals in Indonesia.

Islamic Organization of Wahdah Islamiyah in Palu started with the establishment of a circles of Islamic learning (halaqah tarbiyyah) in 1996 under the Fathul Mu'in Foundation of Makassar. Then, in 1997, the first Daurah Islamiyah was held with the number of participants reaching approximately 10 people and bring two speakers from Makassar. The following year, a second Daurah was held with more than 20 participants, also filled by the teachers and preachers from Fathul Muin Foundation of Makassar.

In 2000, the branch of Wahdah Islamiyah Foundation in Palu City was officially formed. In 2002, after the Foundation officially became a mass organization, Wahdah Islamiyah Foundation in Palu was inaugurated as the Board of Wahdah Islamiyah (DPC-WI) Palu Branch. And after almost 10 years running, based on the results of the Second Conference of Wahdah Islamiyah on 20-22 Muharram 1433/17-19 December 2011 in Makassar, DPC-WI Palu officially changed to Board of Wahdah Islamiyah (DPD-WI) Palu Region. Then, DPD-WI Palu became the official mass organization in Palu City with Certificate of Registered to National Unity, Politics and Public Protection Agency of Palu City, No. 210 / 77a.15 / BKBPL / 2012.

\section{Theological Basis of Wahdah Islamiyah}

Wahdah Islamiyah has a theological concept that is much influenced by the teachings brought by Muhammad ibn 'Abd alWahhāb and his followers. They assume that the surviving group 
(țäifah manșürah) is Ahlussunnah wal Jama'ah, which is in the matter of faith and other religious issues firmly adhere to the Quran, the Sunnah and the guidance of al-Khulafā' al-Rāshidūn. They quote the hadith of Prophet Muhammad: "So hold fast to my Sunnah and the Sunnah of the Rightly-Guided Caliphs who will come after me. Adhere to them and hold fast to them. Beware of Bid'ah (in religion) because every Bid'ah is a misguidance."

The deviant practice of this path is regarded as bid'ah (heresy). In the linguistic sense, the word bid'ah contains a neutral or even useful meaning. However, in religious matters, the word bid'ah contains a negative notion, that is, something new is added to the principles of religion. Ibn Taymiyya defines heresy as "all beliefs and worship that violate the Qur'ān, Sunnah, and ijmā' (agreement) of the salaf scholars ..." .

According to al-Shāfi'ì, bid'ah is divided into two parts: bid'ah mahmüdah (praiseworthy innovation) and bid'ah madhmümah (despicable innovation). Something new that is in accordance with the Sunnah is called mahmüdah, while violating the Sunnah is called madhmūmah. ${ }^{2}$ However, within the frame of the Wahhābi cleric, all forms of heresy are blameworthy and misleading. The word kull in the hadith "kull bid'ah dalalah" ${ }^{3}$ according to Ibn

\footnotetext{
${ }^{1}$ Cited in Sa'īd ibn Nāṣir Al-Ghāmidī, Haqīqah al-Bid'ah wa Aḥkāmuhā, Vol. I. (Riyadh: Maktabah al-Rushd, n.d.), 263.

${ }^{2}$ Cited in 'Izzah 'Al̄̄ 'Ațiyyah, al-Bid'ah: Taḥdīduhā wa Mawqif al-Islām minhāa (Beirut: Dār al-Kitāb al-'Arabī, 1980), 160.

${ }^{3}$ The text of the hadith:

عن عبد الرحمن بن عمرو السلمي و حجر بن حجر قال النبي صلى الله عليه وسلم:أُوْهِيْكُمْ

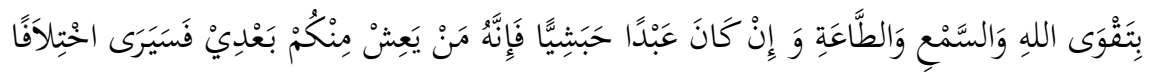

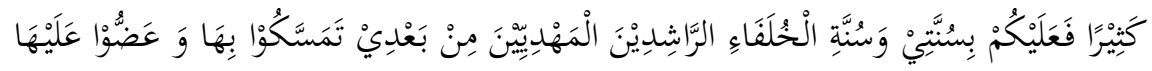

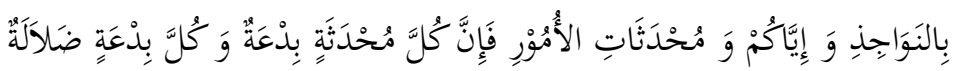


"Uthaymin, leads to the notion of "general and comprehensive" (kulliyyah 'amiyyah shāmilah). Therefore, it is not justified to divide heresy into sections.

The discourse on bid'ah is a notion shaped by fantasies of the ideal "ideal Islamic habitus" or ideal "sunnah habitus". ${ }^{4}$ According to Bourdieu, "habitus tends to ensure its own stability and its resistance to change through the selection it makes in accepting new information by denying information that can question the accumulated information, if exposed to it suddenly or by compulsion, especially by avoiding exposure to information." 5

Sunnah signifies a normative habitus that is supported and approved. Therefore, it must be guarded against the threat of new information that might deprive its purity and stability and normative authority as a set of discourses that demand approval from its followers. Whereas bid'ah is the opposite of sunnah which is unapproved habits and patterns of activity entered into agreed normative structures. The perpetrators commit a sin by choosing with their own desires a habitus that is not approved and

Aḥmad ibn Hanbal, al-Musnad, taḥīq dan takhrīj: Shu'ayb al-Arna'ūṭ, Muhammad Na'īm al-'Ariqsūsī, dan Ibrāhīm al-Zaybaq, dan 'Ādil Murshid, vol 28, hadith no. 17145 (Beirut: Mu'asasah al-Risālah, 1997), 375; Abū Dāwūd Sulaymān ibn al-Ash'ath al-Sijistānī, Ta'līq: 'Izzah 'Ubayd al-Da'ās dan 'Ādil al-Sayyid, Sunan Abī Dāwūd, Jilid 5, "kitāb al-Sunnah," hadith no. 4607 (Beirut: Dār Ibn Ḥazm, 1997), 12-13; Ab̄̄ 'Īsā Muhammad ibn 'Īsa> ibn Sawrah al-Turmudhī, alJāmi ' al-Șhịịh, tahqīq: Ibrāhīm 'Ațwah 'Iwad, vol 5, "bāb mā jā'a fī al-akhdh bi alsunnah wa ijtināb al-bid'ah,” hadith no. 2676 (Mesir: Maṭa'ah Mușțafā al-Bābī al-Halabī, 1975), 44.

4 The term habitus here ia borrowed from Pierre Bourdieu, which refers to the meaning "a product of history which produces individual and collective practices in accordance with the schemes generated by history." Habitus ensures the active presence of past experiences, which, deposited in each organism in the form of schemes, of perception, thought and action, tend to guarantee the 'correctness' of practices and their constancy over time, more reliably than all formal rules and explicit norms.. See Pierre Bourdieu, Logic of Practice, Translated by Richard Nice (Stanford: Stanford University Press, 1990), 52-65.

${ }^{5}$ Ibid., 60-61. 
supported normatively. In fact, the person is considered to have challenged the sovereignty of God as the exclusive lawmaker. And heresy is not limited to the area of positive law, but rather moves on the gaps between law and theology.

Besides bid'ah, the language that is often used to describe deviations from the Qur'ān and Sunnah is the word shirk. Wahdah Islamiyah translates shirk as "believing that other than Allah is entitled to be worshiped, turning things from worship to other than God."6 Shirk in this organizational perspective is divided into three parts: first, the belief in allies for God in ulühiyyah (divinity); second, turning something from pure worship ( $i b \bar{d} d a h$ maḥ̂hah) to other than God; third, shirk in law and obedience. ${ }^{7}$ Included in the third category of shirk is the following practices:

1. The belief that laws other than God's law are better than God's law. It is considered as "great shirk" (al-shirk al-akbar) because he belies the Qur'ān, as cited in the Qur'ān, “Then is it the judgement of [the time of] ignorance they desire? But who is better than Allah in judgement for a people who are certain [in faith]" (Surah Al-Mā'idah (5): 50).

2. One's belief about the allowance of deciding the law with other than what Allah revealed in the Qur'ān.

3. Making a law or regulations contradicting the Qur'ān and the Sunnah of the Prophet, and hold to it in the conviction that being guided by the law is better than the law of God or equal to it.

4. Making the law based on the traditions and customs of its ancestors or tribes, while it is known that it violates God's law,

${ }^{6}$ Administrator, Wahdah Islamiyah Palu, "Syirik dalam Uluhiyah," in http://wahdahpalu.or.id/syirik-dalam-uluhiyyah/ (Access: 30 September 2014). ${ }^{7}$ Ibid. 
believing that tradition is better than the law of God or equal to it. And this is categorised as great shirk.

5. Obeying the law made by the people abiding other than God's law with pleasure, putting his words before God's word, based on hatred of God's law, or believing that it is possible to decide law with it, or believing that it is better than God's law or equal to it. Included in this case are those who follow and obey the customs of certain ethnic community that violate the law of God.

6. Calling on people not to apply the Shari'a, and inviting them to apply positive laws for the sake to fight against and hate Islam, while he knows that he invites to disobedience (munkar) or fight the Sharìa. This practice was incorporated into great shirk and made the perpetrators out of Islam.

Among the practices considered as shirk by Wahdah Islamiyah is the exaltation of the grave by raising the grave, building it, lighting the lamps on it, making rooms on it, building mosques on it. ${ }^{8}$ Wahdah Islamiyah also considers the exaggeration in fostering the pious also as a shirk. ${ }^{9}$ Furthermore, Wahdah Islamiyah claimed that schools or groups, such as Qadariyah and

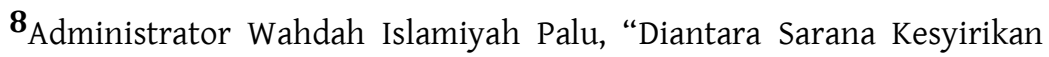
adalah Pengagungan terhadap Kubur," in http://wahdahpalu.or.id/diantarasarana-kesyirikan-adalah-pengagungan-terhadap-kubur/ (Accses: $\quad 30$ September 2014). Their evidence is the hadith of the Prophet:

إلا وإن من كان قبلكم كانوا يتخذون قبور أنبيائهم وصالحيهم مساجد، إني أنهاكم عن ذلك "Those who came before you took the graves of their Prophets and righteous people as places of worship. Do not take graves as places of worship - I forbid you to do that." (Narrated by Muslim in his Sahīh, 532, from Jundab ibn 'AbdAllāh al-Bajalī)

${ }^{9}$ Adminstrator Wahdah Islamiyah Palu, "Sikap Ghuluw dalam Memuji Orang-Orang Shalih," in http://wahdahpalu.or.id/sikap-ghuluw-dalammemuji-orang-orang-shalih/(Access: 30 September 2014).
} 
the extreme Sufis, have performed great shirk. ${ }^{10}$ Hanging a talisman (tamimah) to sick people, children, animals, etc., as a form of "protection" from disaster is also one of the shirk practices. ${ }^{11}$

From the above description about Wahdah Islamiyah's views on theological issues, especially those related to bid'ah and shirk, it can be said that Wahdah Islamiyah has a relatively strict theological view, and this can have serious consequences for one's actions in his or her social, political, economy and cultural environment.

\section{Wahdah Islamiyah on Contemporary Islamic Legal Issues}

\section{Islamic laws on women (figh al-nisā)}

There are several issues discussed by Wahdah Islamiyah Palu on its official website. First, in relation to the concept associated with the hadith of the Prophet, "The voice of women is 'awrah" (sawt al-mar'ah 'awrah). According to Wahdah Islamiyah, female voice is not 'awrah (parts of the body which should not be exposed). Thus, it is not unlawful to hear their voice, unless the sound is intentionally hardened or softened in speech. Such voice is forbidden for woman to do except for her husband, and forbidden for the man other than her husband to listen to her. ${ }^{12}$ In this case, Wahdah Islamiyah quotes a fatwā issued by al-Lajnah alDā'imah li al-Buhūth al-'Ilmiyyah wa al-Iftā'. The basis of their argument is the Qur'ān (al-Aḥzāb (33): 32):

\footnotetext{
${ }^{10}$ Adminstrator Wahdah Islamiyah Palu, "Syirik dalam Rububiyah," in http://wahdahpalu.or.id/syirik-dalam-rububiyyah/ (Access: 30 September 2014).

11Adminstrator Wahdah Islamiyah Palu, "Menggantungkan Jimat (Tamīmah)," in http://wahdahpalu.or.id/menggantungkan-jimat-tamimah/ (Access: 2 Oktober 2014).

12 Adminstrator Wahdah Islamiyah Palu, "Suara Wanita bukan Aurat," in http://wahdahpalu.or.id/suara-wanita-bukan-aurat/ (Access: 30 September 2014).
} 


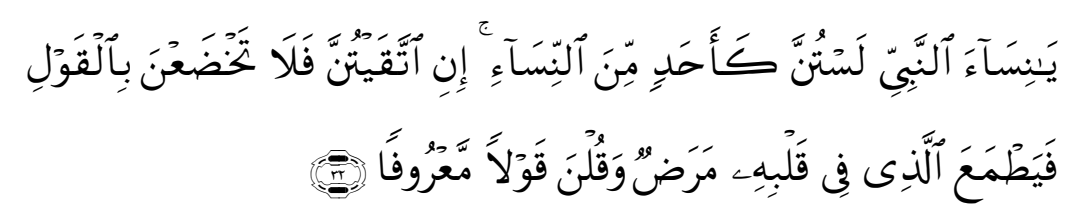

"O wives of the Prophet, you are not like anyone among women. If you fear Allah, then do not be soft in speech [to men], lest he in whose heart is disease should covet, but speak with appropriate speech."

Another issue that concerns the Wahdah Islamiyah group is related to hijāb (veiling). According to Wahdah Islamiyah, law of hijāb is mandatory for Muslim women who is already adult (mukallaf), and is one form of glorification of women who have been prescribed in Islam. ${ }^{13}$ In wearing a hijāb in accordance with the demands of the Sharīa, a woman must cover her whole body and cover all the jewels worn from the view of a man who is not her mahram (close relative whom one cannot marry), based on the word of God: "... and do not expose their adornment..." (QS al-Nūr (24): 31).

In fact, there are women in this organization who wear cadar (veil) as part of their hijäb. For Wahdah Islamiyah's Muslim women, wearing a cadar is a part of their attempt to obey Allah, which in turn will lead them to be true Muslim women. Wearing cadar is also an attempt to manifest piety (taqwa), which is an attempt to gain reward. By wearing a cadar, they seek to adjust their actions to the Sharīa so that they may receive blessings from God. Therefore, Wahdah Islamiyah's women have the view that it is impossible for them to go alone at night without being accompanied by their mahram. Every woman's activities undertaken by the Lembaga Muslimah (Muslim Women Institute) under Wahdah Islamiyah are always flooded with veiled women.

${ }^{13}$ Adminstrator Wahdah Islamiyah Palu, "Menjaga Kehormatan dengan Hijab," in http://wahdahpalu.or.id/menjaga-kehormatan-dengan-hijab/ (Access: 30 September 2014). 
The cadar can be regarded as a "uniform" of female cadres of Wahdah Islamiyah. ${ }^{14}$

Although Wahdah Islamiyah has a rather conservative view of women's issues; however, when looking at the activities of the Lembaga Muslimah, it can be said that women in the Wahdah Islamiyah organization have a significant role in the propagation of $d a$ wah and the organization of social activities. However, their public activity does not conform to the Western conception of the distinction between public and private territories.

\section{Islamic laws on social religious issues}

a. Interfaith marriage

Wahdah Islamiyah affirms the prohibition of interfaith marriages. ${ }^{15}$ They quoted the fatwā of al-Majma' al-Fiqh al-Islāmī (Islamic Fiqh Council), based on the Quranic verse (al-Baqarah [2]: 221), "And do not marry polytheistic women until they believe ..." and al-Mumtahanah (60): 10:

"And if you know them to be believers, then do not return them to the disbelievers; they are not lawful [wives] for them, nor are they lawful [husbands] for them. But give the disbelievers what they have spent."

The repetition of the phrase "they are not lawful [wives] for them, nor are they lawful [husbands] for them" with an emphasis on the prohibition and the termination of the relationship between Muslim women and polytheist men, and the phrase "And give the disbelievers what they have spent," is an order to return the dowry that has been given to his wife if the wife converts to Islam.

14 See Eva F. Nisa, "Cadari of Wahdah Islamiyah: Women as Dedicated Actors of Ultra-conservatism," Intersections: Gender \& Sexuality in Asia \& the Pacific, Issue 30 (Nov 2012).

${ }^{15}$ Adminstrator Wahdah Islamiyah Palu, "Perkawinan Beda Agama," in http://wahdahpalu.or.id/pernikahan-beda-agama/ (Access: 30 September 2014). 
Therefore, the husband do not suffer two losses, loss of wife and property.

According to Wahdah Islamiyah, the women of ahl al-kitāb (the People of the Book), who are muhșanăt (who keep their own honor), may be married by Muslim men. However, it is more suitable for a Muslim not to marry them if there is a free Muslim woman. By quoting Ibn Taymiyyah, Wahdah Islamiyah said that it is makrūh for Muslim men to marry the women of ahl al-kitāb while there were free Muslim women (who could be married).

b. Religious pluralism

Related to the issue of religious pluralism, Wahdah Islamiyah agrees with the fatwā of The Indonesian Ulema Council (MUI), ${ }^{16}$ which forbids religious pluralism and affirms that the notion of pluralism, secularism and religious liberalism is a notion that is contrary to the teachings of Islam. ${ }^{17}$ MUI has its own concept related to these three terms.

Religious pluralism is understood as "a notion that teaches that all religions are the same and therefore the truth of every religion is relative; therefore, every believer cannot claim that only his religion is true while the other religion is wrong. Religious pluralism also teaches that all followers of religion will enter and live side by side in heaven. Meanwhile, religious liberalism is one that understands the texts of religion (the Qur'ān and Sunnah) by using free minds; and accept only religious doctrines that fit the reason alone. And, finally, religious secularism is understood as the separation of world affairs from religion; in other words, religion is used only to regulate personal relationships with God, whereas

${ }^{16}$ Fatwa issued at National Conference MUI VII, on 19-22 Jumadil Akhir 1426 H / 26-29 July 2005 M.

${ }^{17}$ Administrator Wahdah Islamiyah, "Hukum Pluralisme, Liberalisme dan Sekularisme Agama," in http://wahdahpalu.or.id/hukum-pluralismeliberalisme-dan-sekularisme/ (Access: 30 September 2014). 
human relationships are governed only on the basis of social agreement.

\section{Islamic laws on economic issues}

In contemporary economic issues, Wahdah Islamiyah has a relatively conservative view. In the case of bank interest, for example, Wahdah Islamiyah assumes that bank interest is categorised as usury which is forbidden. In this view, Wahdah Islamiyah cited the fatwā issued by al-Majma' al-Fiqh al-Islāmī under the umbrella of the Organization of Islamic Conference in its second meeting in Jeddah, 10-16 Rabi'ul Akhir 1406 H / 22-28 December $1985 \mathrm{M}$.

The same also applies to the issue of insurance. Wahdah Islamiyah forbids commercial insurance in all forms, either life insurance or other insurance. To reinforce this view, Wahdah Islamiyah cited the fatwā of al-Majma' al-Fiqh al-Islāmīat the first symposium held in Mecca on the $10^{\text {th }}$ of Shatbān $1398 \mathrm{H}$. Their argument was reinforced by the following arguments:

a. Commercial insurance contracts include mu'âwadah māliyyah contracts (ie economic transactions such as trade and lease agreements, either in goods or services) that contain very bad gharar (speculation), because the client does not know how much he should pay and how much he will receive, when the contract expires. He may pay a premium once or twice, then if there is a disaster, he or she get insurance funds promised by the agent of insurerance; or they pay the entire premium, but get nothing because there is no disaster. Similarly, the insurer cannot determine the total amount to be given to his colleagues, nor limit the maximum amount of premiums to be paid, whereas the Prophet prohibited the sale that contained gharar (speculative).

b. Commercial insurance contracts are identical to gambling, because there is an element of trying one's luck in the 
management of property for profit. It can also cause loss without error, or otherwise gain profit without any compensation, or with unequal rewards. Because the client may only pay a one-time premium and get a disaster, so the loss is on the side the insurance agency. Or if nothing happens, the agent takes the premium money without any compensation. If a transaction is overwhelmed by such obscurity, it means gambling.

c. Insurance contract contains elements of ribā al-fadl (usury of excess, selling an item for another of the same type, on the spot, but in excess) and ribā al-nasīah (usury of delay, conditional excess for delay of payment). Because when the insurer handed over the insurance money to the clients or to the heirs, or the beneficiary of the insurance; and he gives it more than the total premium paid, it is categorized as riba al-fadl. Then, because the agent of insurance paid the money after a certain period, it means also containing ribā al-nasīah. But if the insurer, after a certain period of time, only gives the same amount of money as the total premium it receives, it only contains ribāal-nasīah, while the two kinds of riba was forbidden based on the Islamic text and the consensus of the scholars (ijmā).

d. Commercial insurance contracts are categorized as a game (rihān) that is forbidden. Because, both the guarantor and the recipient is in uncertainty, great risk (gharar) and gambling. Islam does not allow the game except in matters that benefit Islam and elevate its Sharía through arguments or weapons. The Prophet even limited the game (rihān) only to three things in his words, "No race (sabaq) except camel races, horse races or archery competitions." (Hadith narrated by Ahmad). Insurance does not have any resemblance to it, so it is categorized as forbidden gamble.

e. Commercial insurance contracts contain elements of taking property without any compensation. This is in the legal contract 
of mu'āwadahis prohibited (harām), because it is included in the general scope of the Qur'ān: "O you who have believed, do not consume one another's wealth unjustly but only [in lawful] business by mutual consent. And do not kill yourselves [or one another]. Indeed, Allah is to you ever Merciful."(QS. Al-Nisā': 29).

f. Insurance contracts require something that is not required by Shari'a, because the client does not create calamities of themselves, and it is not him who causes it. What he does is just make a contract with the agent to guarantee himself from the predicted danger that will occur, with money paid to the insurance agent. While the insurance itself does not do anything for the client; therefore, so it becomes forbidden (harām).

\section{Islamic laws on political issues}

Although Wahdah Islamiyah is influenced by the relatively strict theology of Wahhābism in religiosity and morality, but in terms of politics, this organization is less involved in practical politics, although it supports the enforcement of Islamic Sharía. However, unlike other extreme Salafi movements, Wahdah Islamiyah prohibits the use of violence in the propagation of da wah and Islamic law. According to Wahdah Islamiyah, Islam is a religion of peace, not a religion of terrorism. When confronted with the phenomenon of the Islamic State of Iraq and Syria (ISIS) movement, the organization asserts that what ISIS does is not part of the Islamic religion. ${ }^{18}$

In realtion to the state relations, Wahdah Islamiyah holds the view that Muslims are obliged to obey the government as $\bar{u} l \bar{i}$ al'amr, based on the Qur'ān, surah al-Nisā' (4): 59, “Obey Allah, obey

\footnotetext{
${ }^{18}$ Adminstrator Wahdah Islamiyah Palu, "Islam adalah Agama Perdamaian, Bukan Agama Terorisme," in http://wahdahpalu.or.id/islamadalah-agama-perdamaian-bukan-agama-terorisme/ (Access: 30 September 2014).
} 
the Messenger, and $\bar{u} l \bar{i}$ al-amr amongst you." Therefore, when confronted with the issue of the early determination of Ramadhan and Idul Fitri festival, Wahdah Islamiyah, citing the fatwā of the Indonesian Ulema Council (MUI) on January 24, 2004 M (05 Dzulhijjah $1424 \mathrm{H}$ ), affirmed the obligatory obedience to the government; that is, following the determination of fasting and Idul Fitri by the government. ${ }^{19}$

With regard to the issue of elections, Wahdah Islamiyah affirmed that following the election is not the way exemplified by the Prophet, the Companions and the generation of al-salaf al-sālih in upholding the religion and making changes to the life that God desires. However, Wahdah Islamiyah said that Muslims are confronted with the reality that the great forces are openly and hiddenly planning to prevent Islamic da'wah and bring harm to Muslims. One of the ways they take is through various policies and political decisions. In other words, Muslims need to block these efforts, one of which is taking a political path.

It is difficult to find clear text related to this issue. However, in order to prevent or diminish greater dangers, based on the legal maxim: irtikāb al-mafsadah al-șughrā li daf al-mafsadah al-kubrā (taking a less danger in order to prevent greater harms, or yutahamml al-ḍarar alk-khāșs li daf' al-darar al'āmm (preventing general harm by bearing special harm). Therefore, participation in the elections or even becoming a member of parlement, is allowed in order to prevent greater harm. In other words, according to Wahdah Islamiyah, to take on a smaller harm (elections and all the consequences) is a necessity in order to prevent or diminish a greater harm. ${ }^{20}$

\footnotetext{
${ }^{19}$ Adminstrator Wahdah Islamiyah Palu, "Wajib Taat kepada Pemerintah dalam Penetapan Ramadhan dan Hari Raya," in http:// wahdahpalu.or.id/wajibtaat-kepada-pemerintah-dalam-penetapan-ramadhan-dan-hari-raya/ (Access: 30 September 2014).

${ }^{20}$ Adminstrator Wahdah Islamiyah Palu, "Penjelasan Dewan Syari'ah Wahdah Islamiyah tentang Pemilu," in http://wahdahpalu.or.id/penjelasan-
} 


\section{Conclusion}

From the above discussion, it can be concluded that; First, the emergence of Wahdah Islamiyah Palu is an extension of Wahdah Islamiyah in Makassar, founded by alumni of Islamic University in Madinah. These graduates have an ideological relationship with the Medina clerics, who are influenced by the rigid theological teachings of Muhammad ibn 'Abd al-Wahhāb. In the next development, Wahdah Islamiyah spread this Salafi understanding into society. This Salafism is more dominated by theological and juristic doctrines of the scholars such as 'Abd al-"Azīz ibn Bāz, Muhammad ibn Șālih al-'Uthaymīn, Muhammad Nāṣir al-Dīn alAlbānī, and other Medina clerics.

Secondly, with the influence of Wahhabism, Wahdah Islamiyah embraced and accommodated relatively conservative views with various issues in relation to theological issues, which brings into forth the notion of shirk and bid'ah, and Islamic legal issues such as women's, social, economic, and political. From these views, it can be argued that their aim is to preserve the identity by constructing the concepts of shirk and bid'ah and reinforcing the relatively rigid juristic tradition to become the citadel from the attacks of doctrine seeking to demolish the building of Salafism.

\section{References}

'Izzah 'Alī 'Ațiyyah, al-Bid'ah: Taḥdīduhā wa Mawqif al-Islām minhā (Beirut: Dār al-Kitāb al-'Arab̄̄, 1980), 160.

Abū 'Īsā Muhammad ibn 'Īsā ibn Sawrah al-Turmudhī, al-Jāmi' alȘaḥ̂hh, taḥqīq: Ibrāhīm 'Ațwah 'Iwad, vol 5, "bāb mā jā'a fī alakhdh bi al-sunnah wa ijtināb al-bid'ah," hadith no. 2676 (Mesir: Maṭba'ah Muṣțafā al-Bābī al-Ḥalab̄̄, 1975).

dewan-syariah-wahdah-islamiyah-tentang-pemilu/ (Access: 30 September 2014). 
Abū Dāwūd Sulaymān ibn al-Ash'ath al-Sijistānī, Ta'līq: 'Izzah 'Ubayd al-Da'ās dan 'Ādil al-Sayyid, Sunan Abī Dāwūd, Jilid 5, "kitāb al-Sunnah," hadith no. 4607 (Beirut: Dār Ibn Hazm, 1997).

Ahmad ibn Hanbal, al-Musnad, taḥīiq dan takhrīj: Shu'ayb alArna'ūț, Muhammad Na'īm al-'Ariqsūsī, dan Ibrāhīm alZaybaq, dan 'Ādil Murshid, vol 28, hadith no. 17145 (Beirut: Mu'asasah al-Risālah, 1997).

Eva F. Nisa, "Cadari of Wahdah Islamiyah: Women as Dedicated Actors of Ultra-conservatism," Intersections: Gender \& Sexuality in Asia \& the Pacific, Issue 30 (Nov 2012).

Pierre Bourdieu, Logic of Practice, Translated by Richard Nice (Stanford: Stanford University Press, 1990.

Sa'īd ibn Nāṣir al-Ghāmidī, Haqĩqah al-Bid'ah wa Aḥkāmuhā, Vol 1 (Riyāḍ: Maktabah al-Rushd, tt), 263.

\section{Sources from the Internet}

Administrator, Wahdah Islamiyah Palu, "Syirik dalam Uluhiyah," in http://wahdahpalu.or.id/syirik-dalam-uluhiyyah/ (Access: 30 September 2014).

Administrator Wahdah Islamiyah Palu, "Diantara Sarana Kesyirikan adalah Pengagungan terhadap Kubur," in http://wahdahpalu.or.id/diantara-sarana-kesyirikan-adalah -pengagungan-terhadap-kubur/ (Accses: 30 September 2014).

Adminstrator Wahdah Islamiyah Palu, "Sikap Ghuluw dalam Memuji Orang-Orang Shalih," in http://wahdahpalu. or.id/sikap-ghuluw-dalam-memuji-orang-orang-shalih/ (Access: 30 September 2014).

Adminstrator Wahdah Islamiyah Palu, "Syirik dalam Rububiyah," in http://wahdahpalu.or.id/syirik-dalam-rububiyyah/ (Access: 30 September 2014). 
Adminstrator Wahdah Islamiyah Palu, "Menggantungkan Jimat (Tamimah)," in http://wahdahpalu.or.id/menggantungkanjimat-tamimah/ (Access: 2 Oktober 2014).

Adminstrator Wahdah Islamiyah Palu, "Suara Wanita bukan Aurat," in http://wahdahpalu.or.id/suara-wanita-bukanaurat/ (Access: 30 September 2014).

Adminstrator Wahdah Islamiyah Palu, "Menjaga Kehormatan dengan Hijab," in http://wahdahpalu.or.id/menjagakehormatan-dengan-hijab/ (Access: 30 September 2014).

Adminstrator Wahdah Islamiyah Palu, "Perkawinan Beda Agama," in http://wahdahpalu.or.id/pernikahan-beda-agama/ (Access: 30 September 2014).

Administrator Wahdah Islamiyah, "Hukum Pluralisme, Liberalisme dan Sekularisme Agama," in http://wahdahpalu.or.id/hukum-pluralisme-liberalismedan-sekularisme/ (Access: 30 September 2014).

Adminstrator Wahdah Islamiyah Palu, "Islam adalah Agama Perdamaian, Bukan Agama Terorisme," in http://wahdahpalu.or.id/islam-adalah-agama-perdamaianbukan-agama-terorisme/ (Access: 30 September 2014).

Adminstrator Wahdah Islamiyah Palu, "Wajib Taat kepada Pemerintah dalam Penetapan Ramadhan dan Hari Raya," in http://wahdahpalu.or.id/wajib-taat-kepada-pemerintahdalam-penetapan-ramadhan-dan-hari-raya/ (Access: 30 September 2014).

Adminstrator Wahdah Islamiyah Palu, "Penjelasan Dewan Syari'ah Wahdah Islamiyah tentang Pemilu," in http://wahdahpalu.or.id/penjelasan-dewan-syariahwahdah-islamiyah-tentang-pemilu/ (Access: 30 September 2014). 
Vol. 14, Number 2, December 2017: 233-251 